\title{
Screening and identification of bacteriocin-like inhibitory substances producing lactic acid bacteria from fermented products
}

\author{
Thiwanya CHOEISOONGNERN ${ }^{1}$, Bhagavathi Sundaram SIVAMARUTHI ${ }^{1}$, Sasithorn SIRILUN ${ }^{1}$, \\ Sartjin PEERAJAN ${ }^{2}$, Yvan CHOISET ${ }^{3}$, Hanitra RABESONA ${ }^{3}$, Thomas HAERTLÉ ${ }^{3,4,5}$, Chaiyavat CHAIYASUT $^{1 *}$
}

\begin{abstract}
A total of 544 isolates of lactic acid bacteria isolated from fermented products: 451 isolates from fermented products from Thailand and 93 isolated from French fermented products were screened for bacteriocin production. 10 isolates showed antimicrobial activities. Identification of the selected strains by random amplification of polymorphic DNA-polymerase change reaction using the primers E1, E2 and M13 showed three different RAPD patterns. One of the isolates from each product was chosen and good antimicrobial activity were displayed by 3 strains including MP6/2, PKS2-1 and OV1-1 producing in MRS broth bacteriocin-like substance (BLIS) inhibiting Candida albicans ATCC 90028, Carnobacterium maltraromaticum NCDO 2760, Lactobacillus sakei subsp. sakei JCM 1157, Listeria innocula CIP 80.11, Listeria ivanovii SLCC 2379, Pseudomonasc aeruginosa ATCC 27853, Staphylococcus aureus CIP 76.25 and Streptococcus mutans used as indicator strains. However, inhibitory activities of MP6/2 and PKS2-1 were related to the production of either organic acid, while OV2-1 was not affected by heating. The inhibitory activities of these three isolates were sensitive to proteolytic enzymes. $16 \mathrm{~S}$ rDNA gene sequencing allowed to identify the MP6/2 as Pediococcus pentosaceus while PKS2-1 and OV1-1 were identified as Enterococcus faecium. It was concluded that the obtained isolates may be used as bio-preservative cultures to produce fermented foods.
\end{abstract}

Keywords: lactic acid bacteria; bacteriocin; fermented food products; antimicrobial.

Practical Application: The well-characterized bacteriocin-like substance producing lactic acid bacterial strains can be used for the production of functional fermented foods.

\section{Introduction}

Nowadays consumers are aware of the composition of their foods and want to avoid chemical preservatives and taste enhancers like monosodium glutamate. The consumer demands and government regulations push the food manufacturers to find the natural preservatives to control the contaminating microbes, mostly responsible for food spoilage and poisoning. Biopreservation - efficient and natural way of preserving the foods, is defined as employing the non-pathogenic, beneficial bacteria or their secondary metabolites to extend the shelf-life of foods and to increase the microbiological safety.

Lactic acid bacteria (LAB) are Gram-positive rods or cocci, aerotolerant, homofermentative or heterofermentative and lactic acid producers. $\mathrm{LAB}$ can produce organic substances that are responsible for the unique aroma (Caplice \& Fitzgerald, 1999). Lactobacillus, Lactococcus, Carnobacterium, Oenococcus, Melissococcus, Pediococcus, Enterococcus, Leuconostoc, Lactosphaera, Streptococcus, Tetragenococcus, Weissella, and Vagococcus are the common genera of the LAB. The LAB is found in fermented products, beverages, milk and even in meat products, are purposely used to prevent the food spoilage and to enhance the quality of the foods like improved flavor and texture. Most of the known $\mathrm{LAB}$ strains are represented by the genus Lactobacillus, and many of the strains are considered as probiotics (Parada et al., 2007). The LAB is safe and can be used as competitive starter cultures for the controlled fermentation processes (Cintas et al., 2001). Some of the LAB strains produce antagonistic substances when competing with other microbes in the surroundings. These substances are called bacteriocins or bacteriocin-like inhibition substances (BLIS) (Moreno et al., 2000).

Bacteriocins are ribosomally synthesized, small $(<10 \mathrm{kDa})$, bactericidal, heat-stable, antibiotic-like substances, amphiphilic peptides or protein in nature, produced by the LAB. Bacteriocins are primarily defined in Escherichia coli with the name of colicins. Colicins can also kill the same strain or closely related bacteria (Cascales et al., 2007).

Bacteriocins are classified into three classes as following; Class I or lantibiotics, are peptide substances that contain unsaturated amino acids (2- aminoisobutyric acid and dehydroalanine), and polycyclic thioether amino acids (methyllanthionine

${ }^{1}$ Innovation Center for Holistic Health, Nutraceuticals, and Cosmeceuticals, Faculty of Pharmacy, Chiang Mai University, Chiang Mai, Thailand

${ }^{2}$ Health Innovation Institute, Chiang Mai, Thailand

${ }^{3}$ Unitè de Recherche Biopolymères Interactions Assemblages, Institut National de la Recherche Agronomique, Nantes, France

${ }^{4}$ Department of Animal Nutrition and Feed Management, Poznan University of Life Sciences, Poznań, Poland

${ }^{5}$ Institute of Biochemistry and Biophysics, Teheran University, Teheran, Iran

*Corresponding author: chaiyavat@gmail.com 
or lanthionine), Class II or non-lantibiotics, are small, heat stable, non-lanthionine containing membrane peptides. Non-lantibiotics are further separated into two subclasses such as Subclass II a (listeria active bacteriocins or pediocin-like), and Subclass II b (two-component bacteriocins), Class III or bacteriocins, large ( $>30 \mathrm{kDa})$ and heat sensitive. Lactoccin G, Lactococcin MN, Nisin, Leucocin H, Plantaricin W, Plantaricin EF, Plantaricin S, Plantaricin JK, Lactacin F, and Lactocin 705 are common bacteriocins produced by the LAB (Zacharof \& Lovitt, 2012).

$\mathrm{LAB}$ and bacteriocins are considered as safe and are used as biopreservatives. Several reports proved that the fermented foods (FF) are a cheap and major source of bioactive LAB strains. Many $\mathrm{LAB}$ strains isolated from FF are used further as the starters for the preparation of high quality functional FF (Woraharn et al., 2014, 2015). The importance and probiotic nature of LAB in FF have been reported (Angmo et al., 2016; Rhee et al., 2011). Further studies are needed to screen and to identify more commercially important LAB strains that are able to produce BLIS. Thus, the aim of the current study was the screening and the identification of bacteriocin-producing LAB strains from FF of Thailand and France with the potential to be applied in FF production.

\section{Materials and methods}

\subsection{Isolation of Lactic Acid Bacteria (LAB)}

The fermented food (FF) samples were collected from markets in Nantes, France and in Chiang Mai, Northern Thailand. LAB strains were isolated by serial dilution and plating method as described earlier by Woraharn et al. (2014) and stored at $-20^{\circ} \mathrm{C}$ with $20-25 \%$ glycerol as cryoprotectant.

\subsection{Strains and culture condition}

LAB isolates and Lactobacillus sakei subsp. sakei JCM 1157 were maintained at $37^{\circ} \mathrm{C}$ in de Man and Rogosa Sharpe (MRS) media (Himedia, India). The bacterial indicator strains such as L. sakei subsp. sakei JCM 1157 and Listeria ivanovii SLCC 2379 were obtained from Institut National de la Recherche Agronomique (INRA), Nantes, France. Brochothrix thermosphacta DSMZ 20171, Carnobacterium maltaromaticum NCDO 2760, Staphylococcus aureus CIP 7625, Escherichia coli CIP 76.24, and Listeria innocua CIP 80.11 were obtained from Ecole Nationale Nantes Atlantique Vétérinaire, Agroalimentaire et de l'Alimentation (ONIRIS), Nantes, France. Cronobacter sakazakii ATCC BAA-894, E. coli ATCC 5922, Salmonella enterica serovar Typhi (Salmonella Typhi), Pseudomonas aeruginosa ATCC 27853, Shigella sonnei, S. aureus ATCC 5923, Streptococcus mutans, and Bacillus cereus ATCC 11778 were obtained from Facuty of Pharmacy, Chiang Mai University (CMU), Thailand. The indicator strains were sustained in brain heart infusion (BHI) media (Himedia, India). Candida albicans ATCC 90028 was obtained from CMU. Yeast was grown in sabouraud dextrose media (Himedia, India).

\subsection{Assessment of antimicrobial activity}

Agar overlay and agar well diffusion methods were employed as described previously with slight modifications (Birri et al., 2013; Hwanhlem et al., 2014; Sirilun et al., 2017). Briefly, an overnight culture of LAB isolates was stabbed on MRS agar (1.5\% agar) plate and incubated at $37^{\circ} \mathrm{C}$ for $3 \mathrm{hr}$. Then, soft agar $\left(0.8 \%\right.$ agar) containing $10^{6} \mathrm{CFU} / \mathrm{mL}$ indicator strain was overlaid on the plates, and plates were incubated at $37^{\circ} \mathrm{C}$ for $24 \mathrm{hr}$. The formation of clear inhibition zones surrounding the colonies indicated antimicrobial activity.

The cell-free supernatant (CFS) of $24 \mathrm{hr}$ culture of LAB isolates was used for agar well diffusion method as detailed (Hwanhlem et al., 2014; Sirilun et al., 2017).

CFS of positive LAB isolates were treated with catalase (Sigma Aldrich, St. Louis, USA; $1 \mathrm{mg} / \mathrm{mL}$ ) to remove the hydrogen peroxide content and proteinase K (Sigma Aldrich, St. Louis, USA; $1 \mathrm{mg} / \mathrm{mL}$ ) for $1 \mathrm{hr} 37^{\circ} \mathrm{C}$. The treated CFS samples were further analyzed for the antimicrobial activity by agar well diffusion assay.

\subsection{Characterization of Bacteriocin-Like Inhibitory Substances (BLIS)-producing LAB isolates}

BLIS-producing LAB isolates were subjected to Gram staining, and microscopic analysis to check the cell wall pattern, and their shape. Then, the isolates were assayed for catalase activity. The catalase-negative and Gram-positive isolates were further tested for their ability to grow in MRS broth at $45{ }^{\circ} \mathrm{C}$ with $6.5 \% \mathrm{NaCl}$ and $\mathrm{pH} 9.6$.

\subsection{Random Amplification of Polymorphic DNA (RAPD)}

The selected LAB strains were subjected to RAPD analysis to differentiate the strains using E1, E2 (Kirilov et al., 2011) and M13 (Rossetti \& Giraffa, 2005) primers (Supplementary Material, Table S1). Total DNA was extracted from LAB isolates using commercial bacterial DNA extraction kit following the manufactures instructions (E.Z.N.A. ${ }^{\circledR}$ Bacterial DNA Kit, D3350-01, Omega BioTek, USA) and the A260/A280 ratio of DNA samples was determined using a spectrophotometer (BioPhotometer, Eppendorf 6131, USA). PCR reaction was carried out using RAPD primers by following the previously described conditions (Kirilov et al., 2011; Rossetti \& Giraffa, 2005). The amplifications were performed in a Touchgene gradient thermocycler (Techne, UK). The PCR amplicons were separated by electrophoresis at $70 \mathrm{~V}$ on $1.5 \%(\mathrm{w} / \mathrm{v})$ agarose gels with ethidium bromide $(0.5 \mu \mathrm{g} / \mathrm{mL})$, in $0.5 \mathrm{X}$ TAE buffer and the band pattern was observed under UV light.

\subsection{S rDNA gene sequencing}

The representative LAB strains from each RAPD profiled groups were subjected to genomic DNA isolation and 16S rDNA amplification using universal primers ( $\mathrm{fD} 1$ and $\mathrm{rD} 1$; Table $\mathrm{S} 1$ ) (Weisburg et al., 1991). The sequencing of PCR amplicons was done by MilleGen sequencing service (Labège, France). The attained sequences were BLAST with other sequences, and a phylogenetic tree was generated.

\subsection{Effect of heat on bacteriocin activity}

The selected LAB strains were cultured in MRS broth at $37^{\circ} \mathrm{C}$ for $16-24 \mathrm{hr}$, and CFS was collected and filtered through a membrane filter $(0.45 \mu \mathrm{m})$. The filtered CFS was neutralized 
(pH 7.0) by adding sterile $12 \mathrm{~N}$ sodium hydroxide, and incubated at $100^{\circ} \mathrm{C}$ for $0,10,15,30$ and $60 \mathrm{~min}$, and $121^{\circ} \mathrm{C}$ for $15 \mathrm{~min}$. After incubation, CFS samples were assayed for residual bacteriocin activity against $L$. sakei subsp. sakei JCM1157 by agar well diffusion assay (Hwanhlem et al., 2014).

CFS samples were diluted two-fold in $20 \mathrm{mM}$ phosphate buffer and aliquots of $50 \mu \mathrm{L}$ from each dilution were tested against indicator strains by well diffusion method. The activity was represented in arbitrary units per milliliter $(\mathrm{AU} / \mathrm{mL})$ (H-Kittikun et al., 2015) (Equation 1).

$$
\mathrm{AU} / \mathrm{mL}=\frac{1000}{\mathrm{~V}} \mathrm{D}
$$

where: $\mathrm{V}$ is the volume of CFS and $\mathrm{D}$ is the dilution factor.

\subsection{Effect of enzymes on bacteriocin activity}

The neutralized filtered CFS was treated with enzymes (catalase, proteinase $\mathrm{K}, \alpha$-chymotrypsin, and trypsin) at $37^{\circ} \mathrm{C}$ for $4 \mathrm{hr}$, after incubation, the $\mathrm{pH}$ of the solution were neutralized with $100 \mathrm{mM}$ sterile potassium phosphate buffer and the reaction was arrested by heat (H-Kittikun et al., 2015). Bacteriocin activity of the samples was assayed against $L$. sakei subsp. sakei JCM 1157 by agar well diffusion method.

\subsection{Statistical analysis}

All assays were performed in triplicates. The data are stated as the mean \pm standard deviation (SD). Statistical analysis was achieved using SPSS software version 17.0. The data were subjected to one-way analysis of variance (ANOVA) to determine whether there were any differences between the antibacterial activities of samples and control. Significant differences were identified by Duncan test on the level of $\mathrm{P}<0.05$.
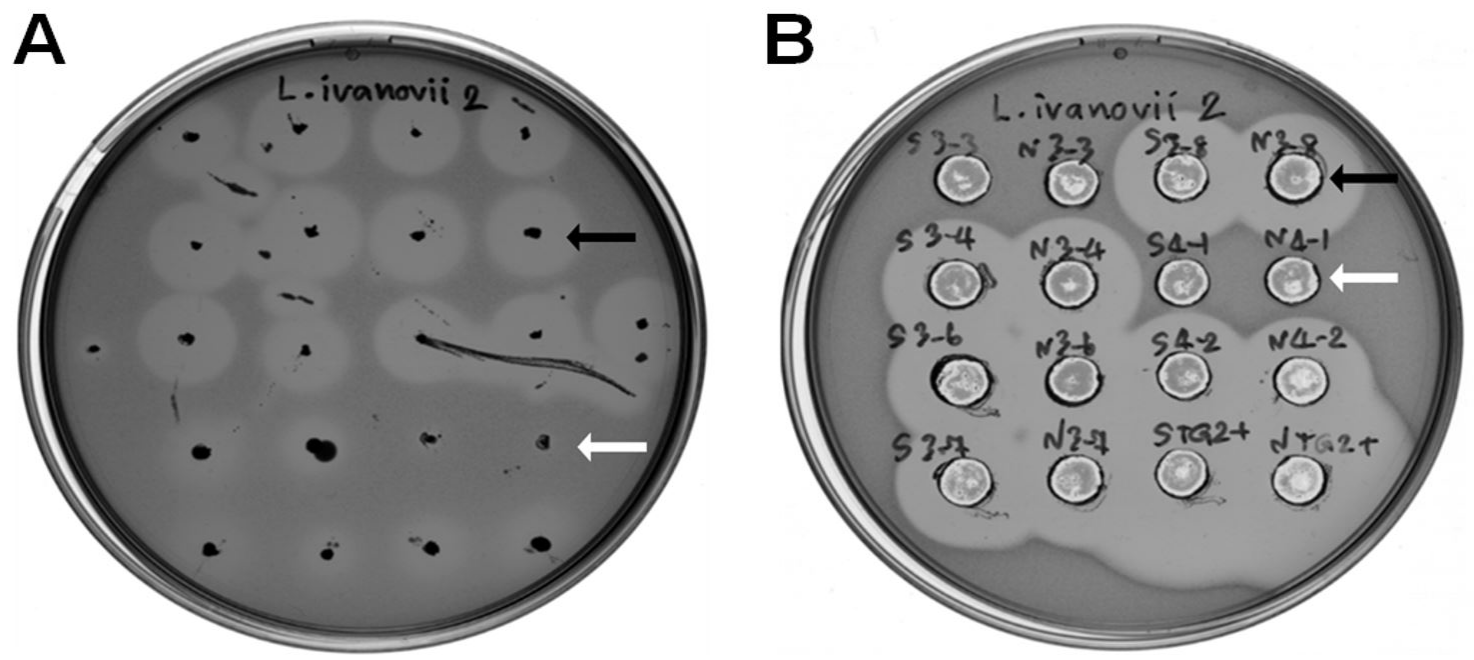

Figure 1. Detection of bacteriocin-like inhibitory substances (BLIS) producing ability of isolated lactic acid bacteria by agar overlay method (A) and agar well diffusion assay (B). The black and white arrows indicate examples of positive and negative result with or without a clear halo zone, respectively. 
Table 1. Antimicrobial activity of isolated lactic acid bacteria revealed by agar well diffusion assay.

\begin{tabular}{|c|c|c|c|c|c|c|c|c|c|c|}
\hline \multirow{2}{*}{ Indicator strains } & \multicolumn{10}{|c|}{ Antimicrobial activity } \\
\hline & MP6/2 & PKS2-1 & PKS2-2 & PKS3-7 & PKS3-8 & PKS4-2 & OV1-1 & OV2-3 & OV3-4 & OV3-6 \\
\hline Bacillus cereus ATCC 11778 & + & + & + & + & + & + & + & + & + & + \\
\hline Brochothrix thermosphacta DSMZ 20171 & - & - & - & - & - & - & - & - & - & - \\
\hline Carnobacterium maltraromaticum NCDO 2760 & + & + & + & + & + & + & + & + & + & + \\
\hline Cronobacter sakazakii ATCC BAA-894 & - & - & - & - & - & - & - & - & - & + \\
\hline Lactobacillus sakei subsp. sakei JCM 1157 & + & + & + & + & + & + & + & + & + & + \\
\hline Listeria innocua CIP 80.11 & + & + & + & + & + & + & + & + & + & + \\
\hline Listeria. ivanovii SLCC 2379 & + & + & + & + & + & + & + & + & + & + \\
\hline Staphylococcus aureus ATCC 5923 & - & - & - & - & - & - & - & - & - & - \\
\hline Staphylococcus aureus CIP 76.25 & + & + & + & + & + & + & + & + & + & + \\
\hline Streptococcus mutans & - & + & - & - & - & - & + & - & - & - \\
\hline Escherichia coli ATCC 5922 & - & - & - & - & - & - & - & - & - & - \\
\hline Escherichia coli CIP 76.24 & - & - & - & - & - & - & - & - & - & - \\
\hline Pseudomonas aeruginosa ATCC 27853 & - & - & - & + & + & - & + & - & + & + \\
\hline Salmonella enterica serovar Typhi & - & - & - & - & - & - & - & - & - & - \\
\hline Shigella sonei & - & - & - & - & - & - & - & - & - & - \\
\hline Candida albicans ATCC 90028 & - & + & + & + & + & + & + & - & + & - \\
\hline
\end{tabular}

-: no inhibition; +: presence $\geq 2 \mathrm{~mm}$. diameter of clear inhibition zones.

Table 2. Bacteriocin-like inhibitory substances producing ability of the isolates revealed by agar well diffusion assay.

\begin{tabular}{cccc}
\hline Isolates & \multicolumn{3}{c}{ Antimicrobial activity (CFS/K) } \\
\cline { 2 - 4 } & L. innocua & L. ivanovii & L. sakei subsp. sakei JCM1157 \\
\hline MP6/2 & $+/-$ & $+++/-$ & $+/-$ \\
PKS2-1 & $+/-$ & $+++/-$ & $++/-$ \\
PKS2-2 & $+/-$ & ++ - & $++/-$ \\
PKS3-7 & $+/-$ & ++ - & $++/-$ \\
PKS3-8 & $+/-$ & $+++/-$ & $++/-$ \\
PKS4-2 & $+/-$ & $+++/-$ & $++/-$ \\
OV1-1 & $+/-$ & $+++/-$ & $++/-$ \\
OV2-3 & $+/-$ & $+++/-$ & $++/-$ \\
OV3-4 & $+/-$ & $+++/-$ & $++/-$ \\
OV3-6 & $+/-$ & $++/-$ & \\
\hline
\end{tabular}

Cell free supernatant (CFS). CFS treated with proteinase K (K). No inhibition (-). $\leq 1$ to $<5 \mathrm{~mm}$ diameter of inhibition zone (+). $\leq 5$ to $<10 \mathrm{~mm}$ diameter of inhibition zone (++). $\leq 10 \mathrm{~mm}$ diameter of inhibition zone $(+++)$.

(M13, E1, and E2), and clear, reproducible amplification patterns were observed (Figure 2). Three different clonal groups were detected based on the RAPD patterns. MP6/2 showed amplification with M13 primer, but no amplification was observed with E1, and E2 primers (clonal group 1). The isolates PKS2-1, PKS2-2, PKS3-7, PKS3-8, and PKS4-2 produced a different pattern (clonal group 2). The isolates OV1-1, OV2-3, OV3-4, and OV 3-6 showed a unique pattern of amplification (clonal group 3) (Table S4).

Three isolates (OV1-1, PKS2-1, and MP6/2), one from each clonal group were selected for molecular identification by partial $16 \mathrm{~s}$ rDNA gene sequencing. A fragment of ( $450 \mathrm{bp}) 16 \mathrm{~s}$ rDNA was amplified and sequenced. The obtained sequences of OV1-1, PKS2-1, and MP6/2 were compared with the GenBank database using the BLAST. Dendrogram construction of the relationship between the $16 \mathrm{~S}$ rDNA gene sequences of three isolates was done by the phylogenetic analysis web server (Phylogeny.fr, 2018) (Figure 3 ). The comparative analysis revealed that the strain MP6/2 from fermented products from Thailand was most similar to Pediococcus pentosaceus, and strain OV1-1 and PKS2-1 from fermented products from France and Thailand, respectively were identified as Enterococcus faecium.

\subsection{Effect of heat and enzymes on bacteriocin activity}

The heat treatment at $100^{\circ} \mathrm{C}$ for 30 min reduced the bacteriocin activity of MP6/2 up to $50 \% .60$ min treatment nullified the activity entirely, while OV1-1 and PKS2-1 conserved 25, and 50\% of activity even after $60 \mathrm{~min}$ of heat treatment. The heating at $121^{\circ} \mathrm{C}$ for fifteen minutes inactivated the MP6/2 activity, whereas OV1-1 and PKS2-1 retained $50 \%$ and $12.5 \%$ of activity after the treatment at $121^{\circ} \mathrm{C}$ for fifteen minutes (Table S5).

Bacteriocin activity of CFS of MP6/2, OV1-1, and PKS2-1 was stable after heating at $100{ }^{\circ} \mathrm{C}$ for ten minutes. However, the activity of MP6/2 and PKS2-1 were decreased by $50 \%$ after neutralization. Catalase treatment has not affected the activity of isolates. $\alpha$-chymotrypsin, proteinase $\mathrm{K}$, and trypsin treatments completely nullified the activity of MP6/2, OV1-1, and PKS2-1 (Table S3). 


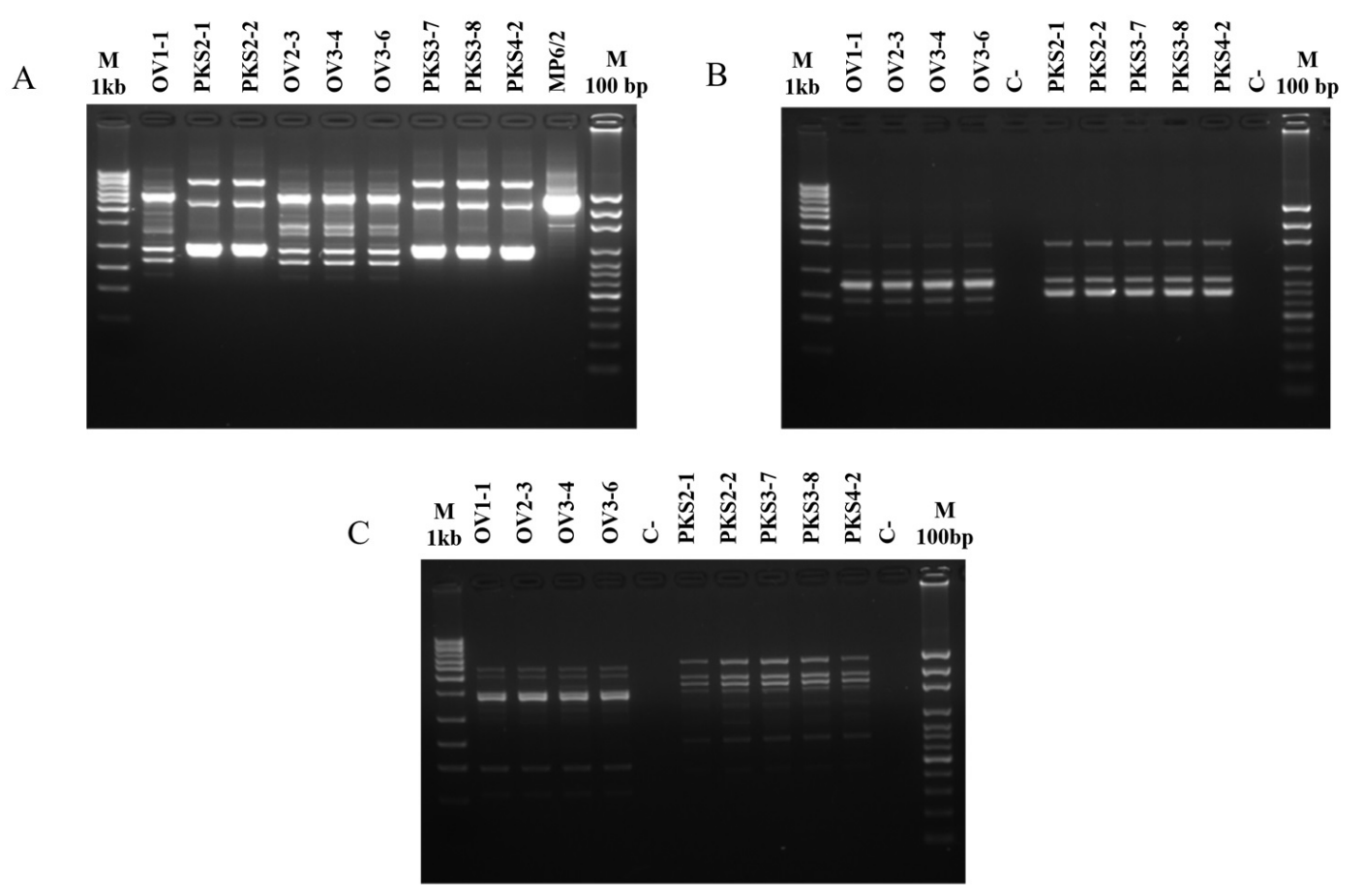

Figure 2. Random amplification of polymorphic DNA-polymerase change reaction (RAPD-PCR) fingerprinting pattern of BLIS-producing LAB isolates with primer M13 (A), primer E1 (B) and primer E2 (C). Lanes M: 100 and 1000 bp ladders.

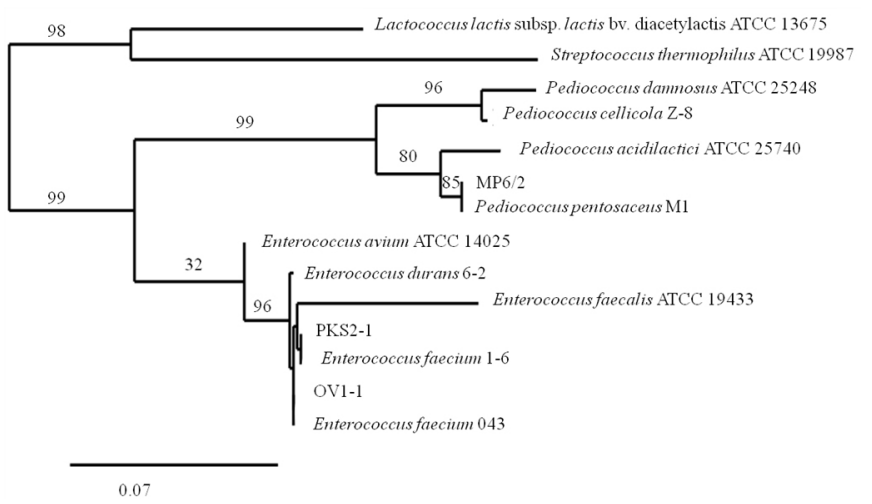

Figure 3. Phylogenetic tree showing the relationship between the 16S rDNA gene sequences of OV1-1, PKS2-1 and MP6/2. The bar indicates 0.07 substitutions per nucleotide position.

\section{Discussion}

About $544 \mathrm{LAB}$ isolates were obtained in primary isolation process, in which many strains were acquired from fermented products from Thailand (451 isolates) and from France (93 isolates). The results indicate that FF from Thailand are abundant in LAB strains. The initial screening by agar overlay results showed that only 11 strains of Thai origin and 15 strains of French origin could produce antimicrobial substances. The CFS of all 26 isolates were neutralized ( $\mathrm{pH}$ 6.5-7.5), neutralization helped to avoid the positive results from the presence of organic acids in CFS. The obtained results showed that only ten isolates can able to produce BLIS (Table S2).
Further study confirmed that the selected ten isolates could hinder the growth of Gram-positive bacteria more effectively than that of the Gram-negative strains, while some isolates showed inhibition against C. albicans (Table 1).

The results suggested that BLIS of selected strains were active against genetically close groups of bacteria. The same scenario was reported previously, E. faecium AQ71 was active against Gram-positive bacteria but not against Gram-negative bacteria like Salmonella spp. and E. coli (Ahmadova et al., 2013). Aspri et al. (2017) reported a spectrum of inhibitory activity of bacteriocin from E. faecium against Gram-positive bacteria. Whereas, bacteriocin CAMT2 produced by Bacillus amyloliquefaciens displayed antimicrobial activity against both Gram-positive and negative bacteria and yeast (An et al., 2015). Likely, L. sakei GM3 displayed a broad spectrum of antagonistic activity against Candida spp., Gram-negative and positive bacterial strains (Avaiyarasi et al., 2016). Likewise, several reports detailing the antagonistic property of bacteriocin-producing microbes, and their activities were mostly varied (Ayed et al., 2015; Biscola et al., 2013; Cavicchioli et al., 2017; Gao et al., 2010).

Bacteriocin and BLIS are peptides or proteins in nature. It has been reported that the screening of the presence of BLIS in CFS required some enzymes and catalase treatment study (Ahmadova et al., 2013). Thus, we have treated the CFS with catalase, to remove $\mathrm{H}_{2} \mathrm{O}_{2}$ from the solution, and with proteinase $\mathrm{K}$, to inactivate the bacteriocins and/or BLIS. Then the samples were tested against representative indicator strains. The obtained results revealed that CFS contains BLIS (Table 2). Ahmadova et al. (Ahmadova et al., 2013) reported that CFS of E. faecium AQ71 showed no activity against indicator strains 
after treating with pronase $\mathrm{E}$, protease type VIII, and protease type $\mathrm{X}$, while catalase, lipase type VII, and $a$-amylase did not affect the activity. The results of the current study revealed that the antimicrobial activity of CFS was attributed to the presence of BLIS,

The morphological and physiological characters such as Gram-positive, cocci, catalase negative, and can grow at $45^{\circ} \mathrm{C}$ in the presence of $6.5 \%$ of sodium chloride at $\mathrm{pH} 9.6$ suggested that the selected LAB strains may belong to Enterococcus (Table S3). RAPD analysis of the strains revealed that all ten strains can be classified into three groups. The most potent strains were selected for molecular identification such as OV1-1, PKS2-1, and MP6/2, representing each clonal group, and found that OV1-1 and PKS2-1 were E. faecium and MP6/2 was P. pentosaceus. Several studies have been reported the BLIS producing E. faecium and P. pentosaceus (Ahmadova et al., 2013; Perumal \& Venkatesan, 2017; Todorov \& Dicks, 2009; Toit et al., 2000; Tulini et al., 2011).

The diversity of bacteriocin in Enterococcus spp. was described earlier (Nes et al., 2007). The bacteriocin of E. faecium 130, isolated from mozzarella cheese, was purified and showed antagonistic activity against Gram-positive bacteria, and activity was stable even after heat treatment at $100{ }^{\circ} \mathrm{C}$ for $15 \mathrm{~min}$, and vast $\mathrm{pH}$ range ( $\mathrm{pH} 2-10)$. The bacteriocin of $E$. faecium 130 was about 3.5 to $6.5 \mathrm{kDa}$ (Tulini et al., 2011). Another cheese isolate and non-virulent, E. faecium AQ71 showed antagonistic activity against LAB, Listeria and Bacillus spp., and harboring enterocins $\mathrm{P}, \mathrm{A}, \mathrm{L} 50 \mathrm{~A}$, and L50B coding genes. The bacteriocin was heat, $\mathrm{pH}$, detergent, and salt stable. The esterase, acid phosphatase, esterase lipase, and aminopeptidase activities were observed in E. faecium AQ71 (Ahmadova et al., 2013). E. faecalis strains isolated from pig feces showed antibacterial activity only against Enterococcus spp. These bacteriocins, about $3-4 \mathrm{kDa}$ in size, were heat stable and exhibited maximum activities at neutral pH. The studied seven strains of E. faecalis (BFE1071, BFE1072, BFE1113, BFE1170, BFE1228, BFE1229 and BFE 1263) were sensitive to a-chymotrypsin, trypsin, proteinase $K$, pepsin, papain, and pronase while showing resistance against lysozyme lipase, and catalase (Toit et al., 2000). Bacteriocin with broad-spectrum antibacterial activity was purified from E. faecalis CV7, vancomycin-resistant strain, and reveled that the bacteriocin was stable against temperature, $\mathrm{pH}$, proteolytic enzymes, detergents, and solvents. It has been proved that the bacteriocin of E. faecalis CV7 has anti-cell proliferative property on HeLa cells. E. faecalis CV7 could be a probiont without any harmful genetic background (Perumal \& Venkatesan, 2017). Another broad-spectrum bacteriocin producing E. faecium GM-1, isolated from infant feces, was described with temperature, and $\mathrm{pH}$ resistance, similar to enterocin P (Kang \& Lee, 2005).

Pediococcus, one of the genera of Lactobacillaceae family, contains Gram-positive lactic acid bacteria, known to produce class IIa bacteriocin with commercial importance as biopreservatives (Papagianni \& Anastasiadou, 2009). A bacteriocin producing Pediococcus pentosaceus was isolated from Sclerocarya birrea was reported. The bacteriocin was active against Gram-positive and Gram-negative bacteria. It had a molecular mass about $6.5 \mathrm{kDa}$ and was class IIa bacteriocin. This bacteriocin was stable at $\mathrm{pH} 2-12$, and temperature at $100{ }^{\circ} \mathrm{C}$ for two hours or at $121^{\circ} \mathrm{C}$ for $20 \mathrm{~min}$. The detergent treatments (Tween 80, Triton X-114, Tween 20, SDS, Triton X-100), urea, EDTA and $\mathrm{NaCl}$ treatments does not affect the activity while proteolytic enzymes inactivate. The strain $P$. pentosaceus ST44AM can produce bacteriocin at $26^{\circ} \mathrm{C}, 30^{\circ} \mathrm{C}$ and $37^{\circ} \mathrm{C}$ without any changes in its activity (Todorov \& Dicks, 2009). P. pentosaceus K34 was isolated from fermented sausages. It can produce bacteriocin named bacPPK34 with the molecular mass of 2.5-6.2 kDa. The bacPPK34 was resistant to detergents, salts, heat, and $\mathrm{pH}$. The bacPPK34 was active against L. monocytogenes and E. faecalis ATCC 29212 (Abrams et al., 2011). Borges et al. (2013, 2014) reported about a bacteriocin producing $P$. pentosaceus SB83 with potential for vaginal application. This bacteriocin resists vaginal conditions and is active against $L$. monocytogenes. Jang et al. (2014) also reported a $P$. pentosaceus bacteriocin active against $L$. monocytogenes. The antimicrobial activity of $P$. pentosaceus Vtcc-B-601 against Gram-negative and -positive bacteria was reported by Nghe \& Nguyen (2014). Likewise, many reports are available on bacteriocin producing $P$. pentosaceus isolated from FF like kimchi (Piva \& Headon, 1994; Shin et al., 2008; Wu et al., 2004).

In the present study, CFS treated with a-chymotrypsin, proteinase and trypsin showed no activity, while catalase and heat treatment did not affect the bioactivity (Table S3 and S5). The results suggested that CFS of selected strains contains BLIS.

\section{Conclusion}

The data represented in the study demonstrated that the fermented products are a rich source of bioactive microbes like bacteriocin producing LAB. The studies revealed that the screened and identified strains, $P$. pentosaceus and E. faecium produce BLIS showing the narrow spectrum of antagonistic activities. The BLIS of P. pentosaceus and E. faecium were heat stable, and $\mathrm{pH}$ resistant. Further characterization of bacteriocin and the evaluation of probiotic properties and absence of virulence factors and antibiotic resistance genes of $E$. faecium and $P$. pentosaceus are under investigation. With these data confirming the absence of detrimental genes, $P$. pentosaceus and E. faecium could be used as a starter culture to prepare fermented products and also be used as biopreservative agents.

\section{Acknowledgements}

This study was supported by Chiangmai University, and scholarship from the Research and Researchers for Industry Program (RRI) to Thiwanya Choeisoongnern under the Thailand Research Fund (TRF). It was also supported from the Graduate School, Chiang Mai University and the French Bio-Asia project from Foreign Affair Ministry.

\section{References}

Abrams, D., Barbosa, J., Albano, H., Silva, J., Gibbs, P. A., \& Teixeira, P. (2011). Characterization of bacPPK34 a bacteriocin produced by Pediococcus pentosaceus strain K34 isolated from "Alheira". Food Control, 22(6), 940-946. http://dx.doi.org/10.1016/j.foodcont.2010.11.029.

Ahmadova, A., Todorov, S. D., Choiset, Y., Rabesona, H., Mirhadi Zadi, T., Kuliyev, A., Franco, B. D. G. M., Chobert, J.-M., \& Haertlé, T. 
(2013). Evaluation of antimicrobial activity, probiotic properties and safety of wild strain Enterococcus faecium AQ71 isolated from Azerbaijani Motal cheese. Food Control, 30(2), 631-641. http:// dx.doi.org/10.1016/j.foodcont.2012.08.009.

An, J., Zhu, W., Liu, Y., Zhang, X., Sun, L., Hong, P., Wang, Y., Xu, C., $\mathrm{Xu}, \mathrm{D}$., \& Liu, H. (2015). Purification and characterization of a novel bacteriocin CAMT2 produced by Bacillus amyloliquefaciens isolated from marine fish Epinephelus areolatus. Food Control, 51, 278-282. http://dx.doi.org/10.1016/j.foodcont.2014.11.038.

Angmo, K., Kumari, A., Savitri, \& Bhalla, T. C. (2016). Probiotic characterization of lactic acid bacteria isolated from fermented foods and beverage of Ladakh. Lebensmittel-Wissenschaft + Technologie, 66, 428-435. http://dx.doi.org/10.1016/j.lwt.2015.10.057.

Aspri, M., O'Connor, P. M., Field, D., Cotter, P. D., Ross, P., Hill, C., \& Papademas, P. (2017). Application of bacteriocin-producing Enterococcus faecium isolated from donkey milk, in the bio-control of Listeria monocytogenes in fresh whey cheese. International Dairy Journal, 73, 1-9. http://dx.doi.org/10.1016/j.idairyj.2017.04.008.

Avaiyarasi, N. D., Ravindran, A. D., Venkatesh, P., \& Arul, V. (2016). In vitro selection, characterization and cytotoxic effect of bacteriocin of Lactobacillus sakei GM3 isolated from goat milk. Food Control, 69, 124-133. http://dx.doi.org/10.1016/j.foodcont.2016.04.036.

Ayed, H. B., Maalej, H., Hmidet, N., \& Nasri, M. (2015). Isolation and biochemical characterisation of a bacteriocin-like substance produced by Bacillus amyloliquefaciens An6. Journal of Global Antimicrobial Resistance, 3(4), 255-261. http://dx.doi.org/10.1016/j. jgar.2015.07.001. PMid:27842869.

Birri, D. J., Brede, D. A., Tessema, G. T., \& Nes, I. F. (2013). Bacteriocin production, antibiotic susceptibility and prevalence of haemolytic and gelatinase activity in faecal lactic acid bacteria isolated from healthy Ethiopian infants. Microbial Ecology, 65(2), 504-516. http:// dx.doi.org/10.1007/s00248-012-0134-7. PMid:23184155.

Biscola, V., Todorov, S. D., Capuano, V. S. C., Abriouel, H., Gálvez, A., \& Franco, B. D. G. M. (2013). Isolation and characterization of a nisin-like bacteriocin produced by a Lactococcus lactis strain isolated from charqui, a Brazilian fermented, salted and dried meat product. Meat Science, 93(3), 607-613. http://dx.doi.org/10.1016/j. meatsci.2012.11.021. PMid:23273471.

Borges, S., Barbosa, J., Silva, J., \& Teixeira, P. (2013). Evaluation of characteristics of Pediococcus spp. to be used as a vaginal probiotic. Journal of Applied Microbiology, 115(2), 527-538. http://dx.doi. org/10.1111/jam.12232. PMid:23611355.

Borges, S., Silva, J., \& Teixeira, P. (2014). The role of lactobacilli and probiotics in maintaining vaginal health. Archives of Gynecology and Obstetrics, 289(3), 479-489. http://dx.doi.org/10.1007/s00404-0133064-9. PMid:24170161.

Caplice, E., \& Fitzgerald, G. F. (1999). Food fermentations: role of microorganisms in food production and preservation. International Journal of Food Microbiology, 50(1-2), 131-149. http://dx.doi. org/10.1016/S0168-1605(99)00082-3. PMid:10488849.

Cascales, E., Buchanan, S. K., Duché, D., Kleanthous, C., Lloubes, R., Postle, K., Riley, M., Slatin, S., \& Cavard, D. (2007). Colicin biology. Microbiology and Molecular Biology Reviews, 71(1), 158-229. http:// dx.doi.org/10.1128/MMBR.00036-06. PMid:17347522.

Cavicchioli, V., Camargo, A., Todorov, S., \& Nero, L. (2017). Novel bacteriocinogenic Enterococcus hirae and Pediococcus pentosaceus strains with antilisterial activity isolated from Brazilian artisanal cheese. Journal of Dairy Science, 100(4), 2526-2535. http://dx.doi. org/10.3168/jds.2016-12049. PMid:28189328.

Cintas, L., Casaus, M., Herranz, C., Nes, I., \& Hernández, P. (2001). Bacteriocins of lactic acid bacteria. Food Science \& Technology
International, 7(4), 281-305. http://dx.doi.org/10.1106/R8DEP6HU-CLXP-5RYT.

Gao, Y., Jia, S., Gao, Q., \& Tan, Z. (2010). A novel bacteriocin with a broad inhibitory spectrum produced by Lactobacillus sake C2, isolated from traditional Chinese fermented cabbage. Food Control, 21(1), 76-81. http://dx.doi.org/10.1016/j.foodcont.2009.04.003.

H-Kittikun, H., Biscola, V., El-Ghaish, S., Jaffres, E., Dousset, X., Pillot, G., Haertlé, T., Chobert, J.-M., \& Hwanhlem, N. (2015). Bacteriocinproducing Enterococcus faecalis KT2W2G isolated from mangrove forests in southern Thailand: purification, characterization and safety evaluation. Food Control, 54, 126-134. http://dx.doi.org/10.1016/j. foodcont.2014.12.037.

Hwanhlem, N., Chobert, J.-M., \& \& H-Kittikun, A. (2014). Bacteriocinproducing lactic acid bacteria isolated from mangrove forests in southern Thailand as potential bio-control agents in food: isolation, screening and optimization. Food Control, 41, 202-211. http://dx.doi. org/10.1016/j.foodcont.2014.01.021.

Jang, S., Lee, J., Jung, U., Choi, H.-S., \& Suh, H. J. (2014). Identification of an anti-listerial domain from Pediococcus pentosaceus $\mathrm{T} 1$ derived from kimchi, a traditional fermented vegetable. Food Control, 43, 42-48. http://dx.doi.org/10.1016/j.foodcont.2014.02.040.

Kang, J., \& Lee, M. (2005). Characterization of a bacteriocin produced by Enterococcus faecium GM-1 isolated from an infant. Journal of Applied Microbiology, 98(5), 1169-1176. http://dx.doi.org/10.1111/ j.1365-2672.2005.02556.x. PMid:15836487.

Kirilov, N., Dimov, S., Dalgalarrondo, M., Ignatova, T., Kambarev, S., Stoyanovski, S., Danova, S., Iliev, I., Haertlé, T., Chobert, J.-M., \& Ivanova, I. (2011). Characterization of enterococci isolated from homemade Bulgarian cheeses and katuk. European Food Research and Technology, 233(6), 1029-1040. http://dx.doi.org/10.1007/ s00217-011-1600-z.

Moreno, I., Lerayer, A. L., Baldini, V. L., \& Leitão, M. F. F. (2000). Characterization of bacteriocins produced by Lactococcus lactis strains. Brazilian Journal of Microbiology, 31(3), 183-191. http:// dx.doi.org/10.1590/S1517-83822000000300007.

Nes, I. F., Yoon, S.-S., \& Diep, D. B. (2007). Ribosomally synthesiszed antimicrobial peptides (bacteriocins) in lactic acid bacteria. Food Science and Biotechnology, 16(5), 675-690.

Nghe, D., \& Nguyen, T. (2014). Characterization of antimicrobial activities of Pediococcus pentosaceus Vtcc-B-601. Journal of Applied Pharmaceutical Science, 4(5), 61.

Papagianni, M., \& Anastasiadou, S. (2009). Pediocins: The bacteriocins of Pediococci. Sources, production, properties and applications. Microbial Cell Factories, 8(1), 3. http://dx.doi.org/10.1186/14752859-8-3. PMid:19133115.

Parada, J. L., Caron, C. R., Medeiros, A. B. P., \& Soccol, C. R. (2007). Bacteriocins from lactic acid bacteria: purification, properties and use as biopreservatives. Brazilian Archives of Biology and Technology, 50(3), 512-542. http://dx.doi.org/10.1590/S1516-89132007000300018.

Perumal, V., \& Venkatesan, A. (2017). Antimicrobial, cytotoxic effect and purification of bacteriocin from vancomycin susceptible Enterococcus faecalis and its safety evaluation for probiotization. Lebensmittel-Wissenschaft + Technologie, 78, 303-310. http://dx.doi. org/10.1016/j.lwt.2016.12.048.

Phylogeny.fr. (2018). Phylogenetic analysis tool. Retrieved from http:// www.phylogeny.fr/index.cgi

Piva, A., \& Headon, D. R. (1994). Pediocin A, a bacteriocin produced by Pediococcus pentosaceus FBB61. Microbiology, 140(4), 697-702. http://dx.doi.org/10.1099/00221287-140-4-697. PMid:8012591. 
Rhee, S. J., Lee, J.-E., \& Lee, C.-H. (2011). Importance of lactic acid bacteria in Asian fermented foods. Microbial Cell Factories, 10(Suppl. 1), S5. http://dx.doi.org/10.1186/1475-2859-10-S1-S5.

Rossetti, L., \& Giraffa, G. (2005). Rapid identification of dairy lactic acid bacteria by M13-generated, RAPD-PCR fingerprint databases. Journal of Microbiological Methods, 63(2), 135-144. http://dx.doi. org/10.1016/j.mimet.2005.03.001. PMid:15893395.

Shin, M., Han, S., Ryu, J., Kim, K., \& Lee, W. (2008). Isolation and partial characterization of a bacteriocin produced by Pediococcus pentosaceus K23-2 isolated from Kimchi. Journal of Applied Microbiology, 105(2), 331-339. http://dx.doi.org/10.1111/j.13652672.2008.03770.x. PMid:18540969.

Sirilun, S., Chaiyasut, C., Sivamaruthi, B. S., Peerajan, S., Kumar, N., \& Periyanaina, K. (2017). Phenethyl alcohol is an effective non-traditional preservative agent for cosmetic preparations. Asian J Pharm Clin Res, 10(8), 129-133. http://dx.doi.org/10.22159/ajpcr.2017.v10i8.18572.

Todorov, S. D., \& Dicks, L. M. (2009). Bacteriocin production by Pediococcus pentosaceus isolated from marula (Scerocarya birrea). International Journal of Food Microbiology, 132(2-3), 117-126. http:// dx.doi.org/10.1016/j.ijfoodmicro.2009.04.010. PMid:19446352.

Toit, M. D., Franz, C., Dicks, L., \& Holzapfel, W. (2000). Preliminary characterization of bacteriocins produced by Enterococcus faecium and Enterococcus faecalis isolated from pig faeces. Journal of Applied Microbiology, 88(3), 482-494. http://dx.doi.org/10.1046/j.13652672.2000.00986.x. PMid:10747229.
Tulini, F. L., Gomes, B. C., \& Martinis, E. C. P. (2011). Partial purification and characterization of a bacteriocin produced by Enterococcus faecium 130 isolated from mozzarella cheese. Food Science and Technology, 31(1), 155-159. http://dx.doi.org/10.1590/S0101-20612011000100022.

Weisburg, W. G., Barns, S. M., Pelletier, D. A., \& Lane, D. J. (1991). $16 \mathrm{~S}$ ribosomal DNA amplification for phylogenetic study. Journal of Bacteriology, 173(2), 697-703. http://dx.doi.org/10.1128/jb.173.2.697703.1991. PMid:1987160.

Woraharn, S., Lailerd, N., Sivamaruthi, B. S., Wangcharoen, W., Peerajan, S., Sirisattha, S., \& Chaiyasut, C. (2015). Development of fermented Hericium erinaceus juice with high content of L-glutamine and Lglutamic acid. International Journal of Food Science \& Technology, 50(9), 2104-2112. http://dx.doi.org/10.1111/ijfs.12873.

Woraharn, S., Lailerd, N., Sivamaruthi, B. S., Wangcharoen, W., Sirisattha, S., \& Chaiyasut, C. (2014). Screening and kinetics of glutaminase and glutamate decarboxylase producing lactic acid bacteria from fermented Thai foods. Food Science and Technology, 34(4), 793-799. http://dx.doi.org/10.1590/1678-457X.6519.

Wu, C.-W., Yin, L.-J., \& Jiang, S.-T. (2004). Purification and characterization of bacteriocin from Pediococcus pentosaceus ACCEL. Journal of Agricultural and Food Chemistry, 52(5), 1146-1151. http://dx.doi. org/10.1021/jf035100d. PMid:14995112.

Zacharof, M., \& Lovitt, R. (2012). Bacteriocins produced by lactic acid bacteria a review article. APCBEE Procedia, 2, 50-56. http://dx.doi. org/10.1016/j.apcbee.2012.06.010. 


\section{Supplementary Material}

Supplementary material accompanies this paper.

Table S1. Primers used in this study.

Table S2. Lactic acid bacteria isolates were isolated from fermented products.

Table S3. Morphology and physiological characteristics of isolates.

Table S4. Results of RAPD fingerprinting BLIS-producing LAB isolates using three primers.

Table S5. Activity of bacteriocin in neutralized cell free supernatants after heating against Listeria ivanovii revealed by agar well diffusion assay.

This material is available as part of the online article from http://www.scielo.br/cta 